\title{
Can horror movies induce PTSD-like syndrome?*1
}

\section{Podem filmes de terror induzir uma síndrome TEPT-símile?}

\author{
Alexandre Xavier Gomes de Araújo*2 \\ Mariana Pires Luz*3 \\ William Berger*4 \\ Luiz Felipe Pagotto*5 \\ Ivan Figueira*6 \\ Mauro V. Mendlowicz*7
}

We reported a case of a 10-year-old girl who developed a PTSD-like syndrome after watching a horror movie. After 6 years, the now 16-year-old patient still fulfilled the DSM-IV criteria for PTSD, except for the trauma itself. We reviewed the scientific literature for case reports of PTSD-like syndrome induced by horror movies and found 13 cases. In only two was the presence of the DSM criteria confirmed. Watching horror movies may thus trigger PTSD-like syndromes in vulnerable viewers

Keywords: Stress disorders, PTSD, mass media, motion pictures

*1 This article is based on the first author's master's degree dissertation Transtorno de Estresse Pós-Traumático, Comorbidade, Qualidade de Vida e Trauma por Exposição Vicária (Filme Comercial) defended in February 19th, 2016, at the Programa de Pós-graduação em Psiquiatria e Saúde Mental do Instituto de Psiquiatria da Universidade Federal do Rio de Janeiro.

*2, 3,4,5, 6 Universidade Federal do Rio de Janeiro - UFRJ (Rio de Janeiro, RJ, Brasil)

${ }^{* 7}$ Universidade Federal Fluminense - UFF (Niterói, RJ, Brasil). 


\section{OBSERVANDO A PSIQUIATRIA}

\section{Introduction}

Posttraumatic stress disorder (PTSD) is, according to the DSM 5 (2013), a severe, persistent and often incapacitating emotional reaction to a stressor that is characterized by twenty symptoms categorized into four clusters: intrusion, avoidance, negative alterations in cognitions and mood, and alterations in arousal and reactivity. To fulfill the criteria A (traumatic event), the person must have been exposed to death, threatened death, actual or threatened serious injury, or actual or threatened sexual violence. The form of exposure to the stressor may be 1) direct exposure, 2) witnessing, in person; 3 ) or indirectly, by learning that a close relative or close friend was exposed to a traumatic event, or 4) repeated or extreme indirect exposure to aversive details of the event(s), usually in the course of professional duties (e.g., first responders, collecting body parts, professionals repeatedly exposed to details of child abuse). The DSM 5 (2013) specifies that the concept of trauma does not include indirect non-professional exposure through electronic media, television, movies, or pictures.

Commercial movies, however, are intended to convey a realistic experience for the viewers. Violent events witnessed on the screen may be felt as distressingly real and could presumably induce psychological harm. Bozzuto (1975) published a pioneering report on what he called "cinematic neurosis": four adults developed panic attacks, sleep disturbances, flashbacks, intrusive thoughts and psychotic symptoms after watching the now classical horror movie "The Exorcist". Soon afterwards, Robinson e Barnett (1975) reported an additional case of "cinematic neurosis" after exposure to another classical scaring movie, "Jaws". The signs and symptoms described in these reports might nowadays be interpreted as of a post-traumatic nature, but the diagnostic category of PTSD would only gain an official status five years later with the publication of the DSM-III (1980). The incidence of stress reactions after exposure to commercial movies,

including avoidance, nightmares, anxiety, flashbacks, and depression, was later estimated to reach $25 \%$ in some populations (Johnson, 1980).

The objective of this study is twofold. The first one is to describe a case in which a persistent and debilitating posttraumatic-like syndrome was triggered by the exposure of a 10-year old girl to a horror movie. This case would have fulfilled the DSM-IV (1994) and DSM 5 (2013) criteria for PTSD were it not for the fact that the stressor was a scene from a movie and not a real world traumatic event. The second goal is to perform a systematic review 
of case reports and case series describing PTSD-like reactions resulting from non-experimental exposure to commercial movies.

\section{Case report}

Ms. P., a 16-year old high school student, was brought by her parents for psychiatric evaluation and treatment. Her mother told that the patient had not been able to sleep alone in her room for several years and any attempt of doing so would cause her unbearable anxiety. In consequence, Ms. P. would sleep in her parents' bed every single night without exception.

Ms. P. was a smiling, cooperative, and well-articulated teenager. She told us that, at age 10, she watched the film "Scary Movie 3" with a friend. Right at this moment, she found the movie quite ridiculous, but at her bed at night, she couldn't sleep due to the fear caused by the scary movie scenes repeatedly playing in her mind. She then moved to her parents' bedroom, where she felt safe and under control. Her mother had to remain awake until she fell asleep to help her withstand the anxiety. With parental encouragement, she attempted several times to sleep alone in her bedroom, but... "my heartbeat raced so much, my hands started sweating, I cried out hard, totally out of control, and I felt as though my organs were trembling inside... I can 't really explain..."

"Scary Movie 3" is a parody of several horror movies, among them "The Ring". In the latter movie, Samara, the main character, was a dead girl with a corpse-like appearance and a straight, shaggy hair that partially hid her scary face. Samara would creep out of the TV screens to commit horrendous murders. At night, intrusive images of Samara's face floating just a few inches from the patient's face appeared when she closed her eyes. Ms. P. would try to keep her eyes open as much as she could to avoid seeing the image of Samara but any attempt of sleeping alone in her bedroom would provoke intense hypervigilance and anxiety.

“... During daytime, I did not believe in Samara, I was pretty much sure that she was not real. The problem was at nighttime, when I went to bed, with this agonizing fear of seeing her. Although I knew she wasn't real, the fear overwhelmed me and I was convinced she would come through the television to haunt me ...".

"... I was extremely anxious and what terrified me the most was to feel that the time was running out and that the night falling, which meant that bedtime was approaching. As the evening grew darker and darker, I had tachycardia and palpitations and began to feel sad ...". 
“... As the night fell, I started to panic; I began taking clonazepam by myself to try to calm down. I would eventually become overcome with fatigue and fall asleep, ... Since my parents couldn't stand anymore seeing me suffering like this, I started sleeping every night in their bedroom ...".

Even though Ms. P. fought continually against her fear of Samara, the intrusive thoughts persisted. She considered covering the TV screen, but she felt that Samara could easily pass through it anyway. Ms. P. avoided staying overnight elsewhere, as she only felt safe sleeping with her parents. She also avoided watching all kind of movies. She didn't report any nightmare.

At school, she felt excluded and isolated, believing her classmates considered her ugly and fat, although she was in fact pretty and thin. She avoided meeting her former friends because ... "I've always been impatient, but I think I have become more impatient than ever with people ..."

Ms. P. would not go anywhere without at least one of her parents, except for school, which was near her home: “... Surely, after watching the movie I felt more afraid to leave home, especially at night. The world became a much more dangerous place ...".

Upon administration of the SCID-IV (Structured Clinical Interview for DSM-IV) (Del-Bem et al., 2001), a semi-structured interview for making the major DSM-IV Axis I diagnosis, we found that Ms. P. would have fulfilled DSM-IV criteria for PTSD were it not for the lack of a real-life traumatic factor. She would also have met the DSM 5 diagnostic criteria for PTSD.

Ms. P. was treated with imaginal exposure alone. During the imaginal exposure exercises, she presented anxiety symptoms, like breathlessness and muscle contractures, mainly in the upper extremities and trunk. The threatening deformed image of Samara would appear, frightening her. She would picture herself sitting wide-eyed and sleepless on her bed all night long. A lost memory in P.'s mind. She was abandoned at an amusement park at age 7. Actually she got last for about 30 minutes. At this very moment, she could identify herself with Samara's suffering: they were both abandoned. Along the treatment, she repeatedly tried to sleep alone in her bedroom, until the moment she was able to sleep an entire night by herself. From this moment on, the image of Samara did not appear anymore. Her fear of abandonment was accentuated. Due to this cognitive reorganization through the mental associations, $P$. became conscious of her true parental bondage and overcame the fear of abandonment. During the last sessions, she was already able to get around her neighborhood and to stay at home alone when her parents went out.

Ms. P. was reassessed 6 months, 1 year and 2 years after the end of the therapy. She remained asymptomatic, sleeping alone and was making plans to 
move abroad to pursue college studies. Furthermore, she managed to establish satisfactory social relationships at high school.

\section{Methods}

We performed a computerized systematic literature search for case reports and case series describing post-traumatic stress disorder-like syndrome emerging after spontaneous, non-experimental exposure to horror movies in the ISI Web of Science, PubMed, PILOTS, PsycINFO, and SCOPUS databases. The fields used were TS (topic), "all fields", "all fields", "all fields", and "TITLEABS-KEY", respectively. The following query was employed across the five databases: (PTSD OR "stress disorder*") AND (film* OR movie* OR cinema OR video OR television). The search was conducted in February 13th, 2015.

Two of the authors (LFP and MPL) independently screened the titles and abstracts of all references. If the source was deemed suitable for inclusion, the full article was obtained and read. Studies were selected based on the inclusion and exclusion criteria (see below). Corresponding authors were

364 contacted when the full text version of potentially relevant articles could not be accessed. Besides the electronic databases searches, hand searches of relevant journals and of the reference lists of identified articles were also conducted. The two authors discussed any disagreement about the inclusion of a study and a third author (WB) was consulted when a consensus decision could not be reached. Experts on the field were consulted too for additional existing studies that might have not been identified by these methods.

The exclusion criteria were: 1) studies involving experimental, non-spontaneous exposure to commercial or non-commercial horror movies; 2) articles describing abnormal psychological reactions to TV news; 3) studies reporting interventional exposure to commercial or non-commercial films (e.g. exposure to movies as part of cognitive-behavior therapy); 4) reviews and theoretical articles; and 5) articles published in languages other than English, French, Portuguese and Spanish

\section{Results}

Our search retrieved 1,767 references that were reduced to 677 with the exclusion of duplicates. After applying inclusion/exclusion criteria, 


\section{OBSERVANDO A PSIQUIATRIA}

two studies were selected. The review of the reference lists retrieved four additional reports, resulting in a total of six relevant studies (see Figure).

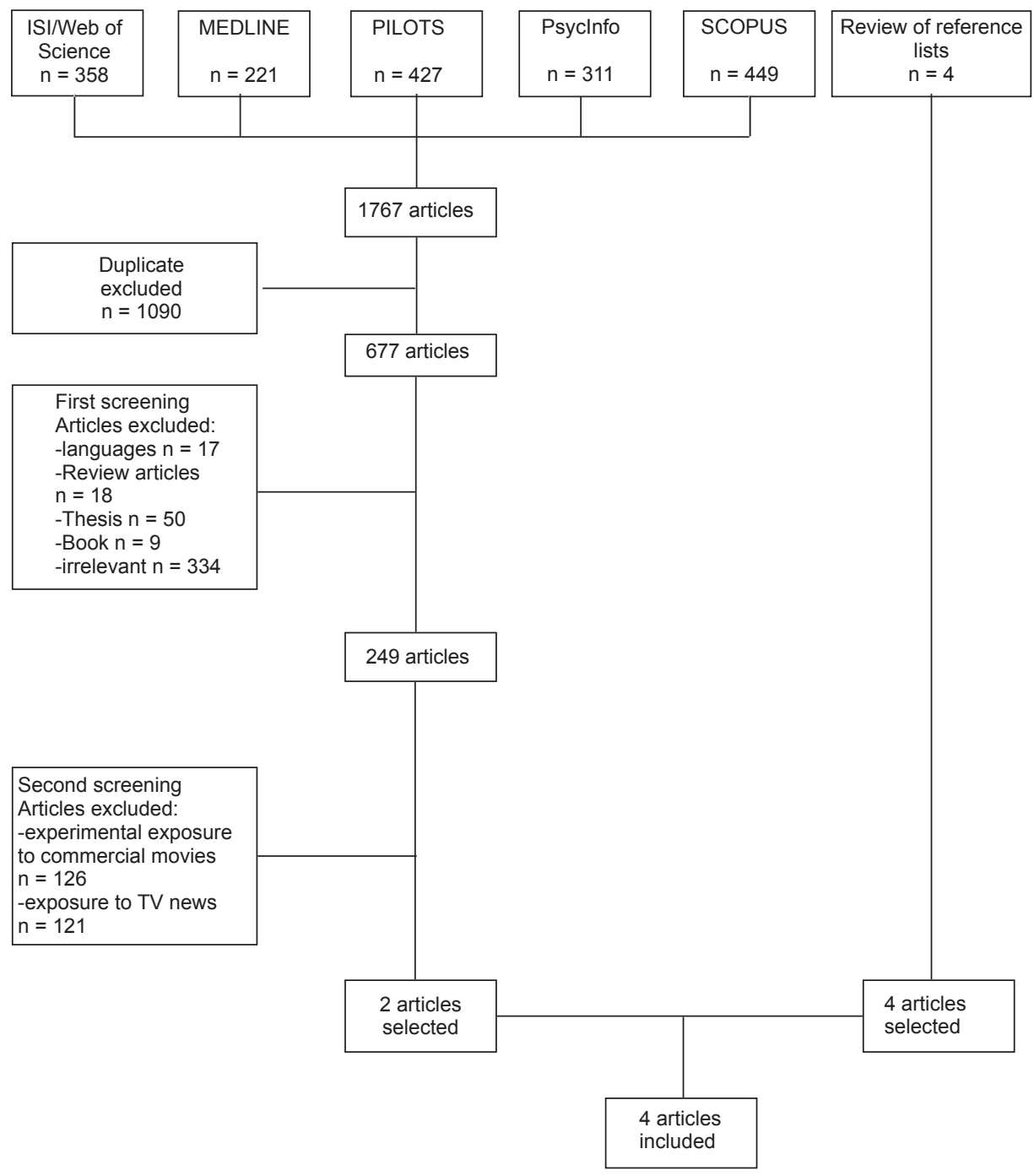

Figure-Flow chart of search results and selection of articles 
These six reports include a total of 13 cases in which clinically significant distress reactions were associated with non-experimental exposure to a horror movie. In eleven cases, psychological reactions ranging from specific phobias to full-blown psychosis were described. In only two cases was a diagnosis of PTSD established according to official diagnostic criteria, the International Classification of Diseases, tenth revision - ICD-10 (World Health Organization, 1992), and the Diagnostic and Statistical Manual of Mental Disorders, Third Edition, Revised - DSM-III-R - (1987). These cases involved 10-year-old boys, who had watched the British TV movie "Ghostwatch", first broadcasted in 1992 (Simons \& Silveira, 1994). The remaining 11 cases - some of them reported before the inclusion of PTSD in official diagnostic classifications (DSM-III) (1980) — included psychological reactions ranging from specific phobias to full-blown psychosis but were not systematically assessed using operationalized diagnostic criteria

(Baillie, Thompson, \& Kaplan, 1994; Bozzuto, 1975; Forbes \& McClure, 1994; Mathai, 1983; Robinson \& Barnett, 1975).

\section{Discussion}

The present study had two main objectives: 1) to report a case of PTSD-like syndrome emerging after spontaneous exposure to a horror movie and diagnosed according to operationalized diagnostic criteria using the SCID-IV (Del-Bem et al., 2001), a semi-structured psychiatric interview; and 2) to perform the first systematic review of case reports and case series describing PTSD-like reactions resulting from non-experimental exposure to horror movies. We concluded that the case reported would have fulfilled diagnostic criteria for PTSD were it not for the fact that the triggering trauma was a movie, not a real-world event. We found in the literature several reports of severe and persistent psychological reactions to films affecting moviegoers, but in only two cases a positive diagnosis of PTSD was made.

Two main issues arise from these findings. First, should horror filmtriggered PTSD-like syndromes be considered real PTSD? And second, what are the mechanisms that can account for the emergence of a PTSD-like syndrome just from watching horror movies in a TV set at home? Regarding the first issue, the answer should be, at least for now, a qualified "no". In the initial DSM-III (1980) formulation, a traumatic event was conceptualized as "a recognizable stressor that would evoke significant symptoms of distress 
in almost everyone" (p. 238) and was generally outside the range of usual human experience (e.g. combat, torture, rape, genocide, earthquakes, airplane crashes). In the DSM-III-R (1987), the core definition of a traumatic stressor as being "outside the range of usual human experience" and "markedly distressing to almost everyone" (p. 250) was retained but was also considerably enlarged to include witnessing or learning about one's family or friends being exposed to serious dangers ("indirect exposure"). The DSM-III-R (1987) introduced a new and important emphasis on the subjective nature of traumatic experience, which was reported to be "usually experienced with intense fear, terror and helplessness". The DSM-IV (1994) and DSM-IV-TR (2000) required that the person experienced, witnessed, or was confronted with an event or events that involved actual or threatened death or serious injury, or a threat to the physical integrity of self or others (Criteria A1) and that his/her response involved intense fear, helplessness, or horror (Criteria A2). The requirements of a stressor "outside the range of usual human experience" that would be "markedly distressing to almost everyone" was dropped. Among the several changes brought by the DSM 5 (2013), particularly noteworthy were the demise of the requirement that the person must have reacted with an intense emotional response (criteria A2), the expansion of the indirect exposure possibilities to include professionals who have never been in direct danger, but who learn about the consequences of a traumatic event day-in and day-out as part of their professional responsibilities (e.g. mortuary workers, rescue workers, emergency medical personnel), and the setting of a "red line" expressly excluding witnessing traumatic events through electronic media, television, video games, or pictures as a traumatic stressor. ICD-10 description has been compatible with the one presented by DSM, thus conditioning the development of PTSD to exposition "to a stressful event or situation (of either brief or long duration) of an exceptionally threatening or catastrophic nature, which is likely to cause pervasive distress in almost anyone."

PTSD ontology has been the object of intense debate, since the concept was developed as if it were the discovery of a natural kind, a thesis which does not seem to be historically confirmed. Some consider that PTSD description is limited to reflecting the extreme point of a natural dimension of responsiveness to stress, whereas others consider the disorder as a socially developed construct. Like other psychiatric disorders, PTSD is defined on the basis of its signals and symptoms, not on its meaning, which is then completely emptied. However, in connection with World Wars I and II there 
are scarce reports of flashbacks, which represent a PTSD hallmark. In fact, there seems to be no latent variable commonly related to several posttraumatic syndromes, such as shell chock and battle fatigue, which may allow their association as manifestations of the same disorder. Therefore, there would be no consolidation of PTSD existence throughout history in the way PTSD is described, which hinders the validity of the latest as a natural kind. The fact which permeates the events seems to be the traumatic event, and even so, as we have seen, its occurrence has been repeatedly redefined so as to be considered as an objective piece of evidence in itself as opposed to a subjective occurrence (McNally, 2012).

From this brief historical review, one can appreciate how the concept of traumatic event has undergone a steady process of "broadening" since its inception, but horror movies remain so far beyond its scope. Yet, as pointed out by McNally (2010), establishing whether a specific stressor possesses or not the capability of causing PTSD is an empirical matter, not a conceptual one. Furthermore, the a priori exclusion of potentially relevant stressors is likely to hinder research and to deny people appropriate treatment and support for their conditions. Considering the large variety of stressors 368 described in the literature (Luz et al., 2011) and the fact that certain studies have reported people developing PTSD like symptoms after exposure to traumatic events that fall short of the official definition of trauma (Mol et al., 2005), an open-minded attitude toward the definition and the boundaries of traumatic stressors is advisable. After all, as pointedly observed by Matthew J. Friedman (2013), the "DSM-5 is a living document that will be modified as new research findings are published" (p. 549).

Based on the case reported above and on our literature review, we propose that horror films can indeed constitute a traumatic stressor under specific circumstances. Most important of these circumstances would be the developmental stage of the patient. In all the three cases of persistent PTSD-like syndrome triggered by horror movies identified so far, the patients were ten-years old at the time of the traumatic exposure. As pointed out by Cantor and Oliver (2004), viewers of different ages are frightened by different components of horror movies. Children from approximately three to eight years are frightened basically by animals, darkness, and supernatural beings, like ghosts, monsters and witches, the more fantastic and grotesque, the more terrifying. In contrast, those aged nine to twelve fear mainly that injury and personal destruction might be inflicted upon them and their dear ones. At this later developmental stage, horror movies 
that were directed primarily at adolescents and adults and that rely basically on threats of physical injury and death to create an atmosphere of terror would become fully capable of traumatizing children who were hitherto unable to understand dangers of a more abstract, nonvisual nature. The traumatizing effects of horror movies during this putative developmental "window of vulnerability" would presumably be compounded by other developmental and circumstantial factors, such as a still limited understanding of the distinction between reality and phantasy, a growing tendency to empathize with a movie protagonist's fear, and the absence of a caring adult to discuss the film with and to soothe the negative emotions attached to it (Cantor \& Oliver, 2004). This state of emotional gradually decrease and eventually disappear with the subsequent emotional and cognitive development of the youngster.

In the reported case, P. had had an experience of being abandoned by her parents in an amusement park at age 7, such experience seeming to have been associated to the event undergone by the movie character, who is abandoned inside a pit. Therefore, throughout the treatment, P.' fear of the character Samara started to be lived by P. as a fear of abandonment. It may be that the original traumatic event lived by $\mathrm{P}$. was its experience in the park at age 7, with such experience having created in her child development a predisposition to the growth of the symptoms triggered by the movie.

Studies have repeatedly shown that adult people often have strong childhood memories of being scared by a movie (Harrison \& Cantor, 1999; Hoekstra, Harris, \& Helmick, 1999). Even more important, up to one third of the respondents reported significant emotional and behavioral disturbances continuing up to the time of the assessment despite the viewers' acknowledgment that this reaction was to a large extent irrational (Cantor, 2004). However, as pointed out by Joanne Cantor and Mary Beth Oliver (2004), the risk of lasting negative psychological consequences or sequelae of horror movies does not imply necessarily that the children should not be allowed to watch them. The ease of access to movies online, peer pressure, the practical limits of parental supervision, among other factors, would make this an unrealistic goal. They suggested, instead, that parental involvement in the selection of films and in coping with the fright eventually triggered by the exposure to one of them would be an appropriate alternative.

Our present study has limitations that warrant discussion. It was based exclusively on cases reports, the number of cases identified was small, most psychiatric diagnoses were made without standardized instruments, and 
modalities of media exposure other than horror movies were not investigated. In spite of these caveats, this study was the first to investigate systematically the association between horror movies and PTSD, the most important psychological sequelae of traumatic exposure. Its findings, while reinforcing previous work in this area, suggest that this an issue that will require more attention from parents, educators, mental health professionals, researchers, and lawmakers, particularly when considering the perspective of accelerated developments in virtual reality and other technological innovations in the entertainment industry.

Acknowledgements: Dr. Mendlowicz is partially supported by the grant 303773/2011-1 from the CNPq (Nacional Research Council) - Federal Government of Brazil.

\section{References}

American Psychiatric Association (Ed.) (1980). Diagnostic and Statistical Manual of Mental Disorders (DSM-III) (Third ed.). Arlington, VA: American Psychiatric Publishing.

American Psychiatric Association (Ed.) (1987). Diagnostic and Statistical Manual of Mental Disorders, -revised (DSM-III-R) (Third ed.). Arlington, VA: American Psychiatric Publishing, Inc.

American Psychiatric Association (Ed.) (1994). Diagnostic and Statistical Manual of Mental Disorders (DSM-IV) (Fourth ed.). Arlington, VA: American Psychiatric Publishing, Inc.

American Psychiatric Association. (2000). Diagnostic and Statistical Manual of Mental Disorders, Fourth Edition, Text Revision (DSM-IV-TR®) (Fourth (Text Revision) ed.). Arlington, VA: American Psychiatric Publishing, Inc.

American Psychiatric Association. (2013). Diagnostic and Statistical Manual of Mental Disorders (DSM-5®). Arlington: American Psychiatric Publishing.

Baillie, M., Thompson, A., \& Kaplan, C. (1994). The terror of television. Anxious children at greater risk. BMJ, 308(6930), 714.

Bozzuto, J. C. (1975). Cinematic Neurosis Following "The Exorcist": Report of Four Cases. Journal of Nervous and Mental Disease, 161(1), 43-48.

Cantor, J. (2004). "I'll never have a clown in my house" - Why movie horror lives on. Poetics Today, 25(2), 283-304. 


\section{OBSERVANDO A PSIQUIATRIA}

Cantor, J., \& Oliver, M. B. (2004). Developmental differences in responses to horror. In S. Prince (Ed.), The Horror Film (pp. 224-241). New Brunswick, NJ: Rutgers University Press.

Del-Bem, C. M., Vilela, J. A. A., Crippa, J. A. S., Hallak, J. E. C., Labate, C. M., \& Zuardi, A. W. (2001). Reliability of the Structured Clinical Interview for DSM-IV - Clinical Version translated into Portuguese. Revista Brasileira de Psiquiatria, 23(3), 156-159.

Forbes, F., \& McClure, I. (1994). The terror of television. Made worse by family stress. BMJ, 308(6930), 714.

Friedman, M. J. (2013). Finalizing PTSD in DSM-5: Getting here from there and where to go next. Journal of Traumatic Stress, 26(5), 548-556.

Harrison, K., \& Cantor, J. (1999). Tales from the screen: Enduring fright reactions to scary media. Media Psychology, 1(2), 97-116.

Hoekstra, S. J., Harris, R. J., \& Helmick, A. L. (1999). Autobiographical memories about the experience of seeing frightening movies in childhood. Media Psychology, 1(2), 117-140.

Johnson, B. R. (1980). General occurrence of stressful reactions to commercial motion pictures and elements in films subjectively identified as stressors. Psychological Reports, 47(3 Pt 1), 755-786.

Luz, M. P., Mendlowicz, M., Marques-Portella, C., Gleiser, S., Berger, W., Neylan, T. C., Figueira, I. (2011). PTSD Criterion A1 events: A literature-based categorization. Journal of Traumatic Stress, 24(3), 243-251.

Mathai, J. (1983). An acute anxiety state in an adolescent precipitated by viewing a horror movie. Journal of Adolescence, 6(2), 197-200.

McNally, R. J. (2010). Can we salvage the concept of psychological trauma? Psychologist, 23(5), 386-389.

McNally, R. J. (2012). The ontology of posttraumatic stress disorder: natural kind, social construction, or causal system? Clin Psychol Sci Prac 19, 220-228.

Mol, S. S., Arntz, A., Metsemakers, J. F., Dinant, G.-J., Vilters-van Montfort, P. A., \& Knottnerus, J. A. (2005). Symptoms of post-traumatic stress disorder after non-traumatic events: evidence from an open population study. British Journal of Psychiatry, 186(6), 494-499.

Robinson, J., \& Barnett, A. (1975). Letter: Jaws Neurosis. New England Journal of Medicine, 293(22), 1154.

Simons, D., \& Silveira, W. (1994). Post-traumatic stress disorder in children after television programmes. BMJ, 308(6925), 389-390.

World Health Organization. (1992). The ICD-10 classification of mental and behavioural disorders: clinical descriptions and diagnostic guidelines. Geneva: World Health Organization. 


\begin{abstract}
(Podem filmes de terror induzir uma síndrome TEPT-símile?)

O caso de uma menina de 10 anos de idade que desenvolveu síndrome do tipo transtorno de estresse pós-traumático (TEPT) após assistir a filme de terror é relatado. Após seis anos, a paciente ainda preenchia os critérios do DSM-IV para TEPT. Em revisão da literatura, identificamos 13 casos de síndrome TEPT-símile induzida por filmes de terror, mas o diagnóstico baseado em critérios DSM foi feito em dois casos apenas. Filmes de terror podem desencadear sindromes TEPT-símile em pessoas vulneráveis.

Palavras-chave: Transtornos de estresse, TEPT, mídia, cinema

(Les films d'horreur peuvent-ils induire un syndrome semblable au SSPT?)

Cet article décrit le cas d'une jeune fille de 10 ans qui a développé un syndrome qui ressemble à celui du stress post-traumatique (SSPT) après avoir regardé un film d'horreur. Six ans plus tard, la patiente présentait toujours les symptômes du SSPT correspondants aux critères du DSM-IV. La littérature scientifique a été examinée à la recherche de cas semblables et treize cas semblables ont été recensés. La présence des critères DSM-IV a été confirmée uniquement dans deux cas. Nous concluons que l'exposition à des films d'horreur peut déclencher un syndrome du type SSPT chez les personnes vulnérables.
\end{abstract}

Mots clés: Troubles de stress, SSPT, médias, cinéma

(¿Pueden las películas de terror inducir a un trastorno similar al TEPT?)

Presentamos el caso de una niña de 10 años que desarrolló un síndrome tipo trastorno de estrés postraumático (TEPT) después de ver una película de terror. Al cabo de seis años, la paciente aún cumplía con los criterios del DSM-IV para el TEPT. Durante la revisión de la literatura, identificamos 13 casos de síndromes similares al TEPT, inducidos por películas de terror, pero el diagnóstico basado en los criterios DSM fue hecho solo en dos casos. Películas de terror pueden desencadenar sindromes similares al TEPT en espectadores vulnerables.

Palabras clave: Trastornos de estrés, TEPT, medios de comunicación, películas

(Können Horrorfilme ein PTBS-ähnliches Syndrom induzieren?)

Dieser Artikel beschreibt den Fall eines 10-jährigen Mädchens, das ein PTBSähnliches Syndrom entwickelte, nachdem sie einen Horrorfilm angeschaut hatte. Sechs Jahre später zeigte die nun 16 Jahre alte Patientin nach wie vor PTBS Symptome auf, die den Kriterien des DSM-IV entsprachen. Wir forschten in der wissenschaftlichen Literatur nach Fallberichten des PTBS-ähnlichen Syndroms, die durch Horrorfilme induziert wurden und fanden 13 Fälle. In nur zwei Fällen wurden die DSM-IV-Kriterien 


\section{OBSERVANDO A PSIQUIATRIA}

bestätigt. Wir kommen zum Schluss, dass bei anfälligen Personen, die sich Horrorfilmen aussetzen, es zu PTBS-ähnlichen Syndromen kommen kann.

Schlüsselwörter: Stresserkrankungen, PTBS, Medien, Kino

Citação/Citation: Araújo, A. X. G., Luz, M. P., Berger, W., Pagotto, L. F., Figueira, I. (2019, junho). Can horror movies induce PTSD-like syndrome?. Revista Latinoamericana de Psicopatologia Fundamental, 22(2), 360-375. http://dx.doi.org/10.1590/1415-4714.2019v22n2p360.11.

Editor/Editor: Prof. Dr. Octávio Domont de Serpa Jr.

Submetido/Submitted: 25.3.2018/ 3.25.2018 Revisado/Revised: 26.2.2019 / 2.26.2019

Aceito/Accepted: 26.4.2019/4.26.2019

Copyright: (C) 2009 Associação Universitária de Pesquisa em Psicopatologia Fundamental/ University Association for Research in Fundamental Psychopathology. Este é um artigo de livre acesso, que permite uso irrestrito, distribuição e reprodução em qualquer meio, desde que $\mathrm{o}$ autor e a fonte sejam citados / This is an open-access article, which permits unrestricted use, distribution, and reproduction in any medium, provided the original authors and sources are credited.

Financiamento/Funding: Este trabalho não recebeu financiamento / This work not received funding.

Conflito de interesses/Conflict of interest: Os autores declaram que não há conflito de interesses / The authors declare that there is no conflict of interest.

Alexandre Xavier Gomes de Araújo

Graduado em medicina pela Universidade Federal Fluminense - UFF (Niterói, RJ, Br). Especialização em psiquiatria pela UFF e concluiu mestrado em psiquiatria pelo IPUB/UFRJ (Rio de Janeiro, RJ, Br) em 2016. É professor adjunto do departamento de psiquiatria da UFF. Rua das Laranjeiras, 102/703

22240000 Rio de Janeiro. RJ, Br

https://orcid.org/0000-0002-1298-8197

alexandrepsimed@gmail.com 


\section{Mariana Pires Luz}

Formada em Medicina pela Universidade Federal do Rio de Janeiro - UFRJ (Rio de Janeiro, RJ, Br). Possui residência médica em Psiquiatria e Psiquiatria Geriátrica pelo Instituto de Psiquiatria da Universidade Federal do Rio de Janeiro. É médica assistente e preceptora da residência médica da Universidade Federal do Rio de Janeiro. Concluiu o Mestrado e Doutorado em Psiquiatria na Universidade Federal no Rio de Janeiro - UFRJ (2010 e 2014, respectivamente).

Rua Sorocaba $782 / 502$

22271-110. Rio de Janeiro, RJ, Br

https://orcid.org/0000-0002-0297-5245

mariluz@centroin.com.br>

\section{WiLliam Berger}

Possui mestrado (2006) e doutorado (2011) em Psiquiatria e Saúde Mental pela Universidade Federal do Rio de Janeiro - IPUB/UFRJ (Rio de Janeiro, RJ, Br). Trabalhou durante 1 ano na University of California, San Francisco (UCSF) e no San Francisco Veterans Affairs Medical Center (VAMC) como Visiting Scholar, atuando principalmente como pesquisador na área de transtorno do estresse pós-traumático. Foi professor adjunto de Psiquiatria (2014) da Universidade Federal Fluminense - UFF (Niterói, RJ, Br)), e atualmente é professor adjunto de Psiquiatria do IPUB/UFRJ, além de coordenador e docente permanente do Programa de Pós-Graduação em Psiquiatria e Saúde Mental (PROPSAM) dessa mesma faculdade. Atualmente é membro da comissão de trabalho e estudos em Violência, estresse e trauma da Associação Brasileira de Psiquiatria (ABP). Tem experiência na área de Medicina, com ênfase em Psiquiatria, atuando principalmente nos seguintes temas: transtorno de estresse pós-traumático, epidemiologia, memória, psicofarmacologia, tradução e TEPT.

https://orcid.org/0000-0002-7095-6636

Rua Leite Leal, 135, bl 2, apto 101

22240-100 Rio de Janeiro, RJ,Br

https://orcid.org/0000-0002-7095-6636

wberger@globo.com

\section{Luiz Felipe Pagotto}

Possui graduação em Medicina pela Universidade Federal do Estado do Rio de Janeiro UNIRIO (Rio de Janeiro, RJ, Br). Especialização em Psicoterapia Psicodinâmica Breve pela Santa Casa de Misericórdia do Rio de Janeiro (2007). Especialização em Psiquiatria pelo IPUB da Universidade Federal do Rio de Janeiro - UFRJ (Rio de Janeiro, RJ, Br) (2009). Mestrado em Psiquiatria pelo IPUB/UFRJ (2014).

Rua Mem de Sá, 111/705

24220-261 Niterói, RJ, Br

https://orcid.org/0000-0002-0635-3224

lfpagotto@globo.com

\section{IVAN FigueIRA}

Graduado em Medicina pela Universidade Federal do Rio de Janeiro - UFRJ (Rio de Janeiro,RJ, Br), doutorado pela Universidade Federal do Rio de Janeiro (1993) e pósdoutorado pela UFRJ (1999). Atualmente é Professor Associado da Faculdade de Medicina 


\section{OBSERVANDO A PSIQUIATRIA}

da Universidade Federal do Rio de Janeiro e Coordenador da Área de Psiquiatria da Pós-graduação em Psiquiatria e Saúde Mental do Instituto de Psiquiatria da UFRJ (IPUB). Coordena também o Laboratório Integrado de Pesquisa do Estresse - LINPES, do IPUB. Foi Vice-Coordenador do Instituto do Milênio de Violência e Saúde Mental do CNPq. Tem experiência na área de Medicina, com ênfase em Psiquiatria, atuando principalmente nos seguintes temas: transtorno do estresse pós-traumático, fobia social, transtorno do pânico, farmacoterapia dos transtornos de ansiedade e cienciometria.

Avenida Nossa Senhora de Copacabana 400/802

22020-001 Rio de Janeiro, RJ, Br

https://orcid.org/0000-0002-8155-0519

ivanfigueira13@gmail.com

\section{Mauro Vitor Mendlowicz}

Possui graduação em Medicina pela Universidade do Estado do Rio de Janeiro (1982) e doutorado em Psiquiatria e Saúde Mental pela Universidade Federal do Rio de Janeiro (1994). Pós-doutorado pela University of California at San Diego (1996-1998). Atualmente é professor associado da Universidade Federal Fluminense. Tem experiência na área de Medicina, com ênfase nos aspectos neurobiológicos e clínicos dos transtornos relacionados ao estresse, atuando principalmente nos seguintes temas: transtorno do estresse pós-traumático, trauma, violência, homicídio e transtornos de ansiedade.

Rua Tiradentes, 171 - bloco 2/apto. 903

24210-510 Niterói, RJ, Br

https://orcid.org/0000-0002-8891-0548

mmendlowicz@yahoo.com

This is an open-access article, which permits unrestricted use, distribution,

(cc) BY-NC and reproduction in any medium for non-commercial purposes provided the original authors and sources are credited. 